\begin{tabular}{|l|l|l||}
\hline \multicolumn{2}{|c|}{ PublisherInfo } \\
\hline \hline PublisherName & $:$ & BioMed Central \\
\hline \hline PublisherLocation & $:$ & London \\
\hline \hline PublisherImprintName & $:$ & BioMed Central \\
\hline \hline
\end{tabular}

\title{
Mighty splicing machine
}

\begin{tabular}{|l|l|l||}
\hline \multicolumn{2}{|c|}{ ArticleInfo } \\
\hline \hline ArticleID & $:$ & 4583 \\
\hline \hline ArticleDOI & $:$ & $10.1186 /$ gb-spotlight-20020917-02 \\
\hline \hline ArticleCitationID & $:$ & spotlight-20020917-02 \\
\hline \hline ArticleSequenceNumber & $:$ & 249 \\
\hline \hline ArticleCategory & $:$ & Research news \\
\hline \hline ArticleFirstPage & $:$ & 1 \\
\hline \hline ArticleLastPage & $:$ & 2 \\
\hline \hline & & RegistrationDate : 2002-9-17 \\
\hline ArticleHistory & $:$ & OnlineDate \\
\hline \hline ArticleCopyright & $:$ & BioMed Central Ltd2002-17 \\
\hline \hline ArticleGrants & $:$ & \\
\hline \hline ArticleContext & $:$ & 130593311 \\
\hline \hline
\end{tabular}




\section{Jonathan B Weitzman}

Email: jonathanweitzman@hotmail.com

The spliceosome is a macromolecular machine, containing five small nuclear RNAs and a number of proteins, that is responsible for the excision of introns from pre-mRNA species. In the September 12 Nature, Zhou et al. report a complete proteomic analysis of all the polypeptide components of the spliceosome complex (Nature 2002, 419:182-185). They assembled spliceosomes on adenovirus major late pre-mRNA (AdML-M3), which contains three hairpins and can be affinity-purified using a bacteriophage coat protein fused to maltose-binding protein (MS2-MBP fusion protein). Zhou et al. demonstrate that the intact complex is highly purified and functional. They examined the protein components by liquid chromatography tandem mass spectrometry (LC-MS/MS) and found around 145 distinct polypeptides; including 88 known splicing-associated proteins. The rest of the proteins had not been previously linked to splicing and include several involved in regulating gene expression, transcription and mRNA export.

\section{References}

1. Pre-mRNA splicing in the new millennium.

2. Nature, [http://www.nature.com] 